\title{
THE USE OF ZEOLITE FOR WATER QUALITY MANAGEMENT IN COLD WATER RECIRCULATION AQUACULTURE SYSTEMS
}

Gražina ŽIBIENĖ, Hydraulic Engineering Institute, Faculty of Water and Land Management, ${ }^{1}$ Vytautas Magnus University, K. Donelaičio g. 58, Kaunas, Lithuania. grazina.zibiene@vdu.lt (corresponding author)

Alvydas ŽIBAS, Hydraulic Engineering Institute, Faculty of Water and Land Management, ${ }^{1}$ Vytautas Magnus University, K. Donelaičio g. 58, Kaunas, Lithuania. alvydas.zibas@ vdu.lt

This study was performed to evaluate use of zeolite for water quality management in cold water recirculating aquaculture system. The system was reared Arctic charr (Salvelinus alpinus) and Hybrid char (Salvelinus fontinalis $\times$ Salvelinus alpinus) fry. Fish biomass in the reservoirs was distributed as follows: Arctic charr accounted for $7.32 \mathrm{~kg}$ at a density of $23.74 \mathrm{~kg} \cdot \mathrm{m}^{-3}$, and hybrid charr accounted for $7.78 \mathrm{~kg}$ at a density of $26.91 \mathrm{~kg} \cdot \mathrm{m}^{-3}$. After increasing the feed rate and documenting water quality studies, a vast increase of ammonium and nitrite concentration was noticed in the rearing tanks. Natural zeolite, known as clinoptilolite with a cation exchange capacity (CEC) of $1.20-1.50 \mathrm{~mol} \cdot \mathrm{kg}^{-1}$, was used to reduce the amounts of these hazardous substances in the rearing tanks. Zeolite was used to decrease the increased concentration of ammonia and nitrites, which were reduced by $22.7 \%$ and $16.7 \%$, respectively, during the study period. These results suggest that zeolite is suitable for water quality management in cold water recirculating aquaculture system with as little of an investment as possible.

Keywords: Arctic charr, Hybrid charr, recirculating aquaculture system, water quality management, zeolite

\section{INTRODUCTION}

When fish are cultivated for industrial purposes, i.e., at high density and using large amounts of feed, fish metabolism products and unused feed pollute the water where the fish grow. The management of water quality parameters in recirculating aquaculture systems (RAS) is important to successfully develop cultivation. One of the main disadvantages of intensive RAS is the toxic influence of accumulated ammonia in the water tank. Ammonia's toxic influence can be reduced by increasing the water metabolism using the nitrification method or the ion exchange process. Either synthetic or natural zeolites can be used.

Zeolites are hydrated aluminum silicates that have a crystal structure and are able to absorb many different types of gas, odors, humidity, oil chemical products, ammonia, heavy metals, low level radioactive elements and various other solutions (Ghasemi et al., 2016). Ion metabolism is the main ammonia absorption theory based on CLP (Zhang, 2017; Almutairi and Weatherley, 2015). Zeolite has a natural negative charge, which gives it high cation-exchange capacity (CEC). It absorbs ammonia ions as well as other cations dissolved in water and removes heavy metal cations $(\mathrm{Pb}, \mathrm{Cu}, \mathrm{Cd}, \mathrm{Zn}, \mathrm{Co}$, $\mathrm{Cr}, \mathrm{Mn}$ and $\mathrm{Fe}$, with almost $97 \%$ of $\mathrm{Pb}$ and $\mathrm{Cu}$ being removed), organic waste and undesirable odors in the water. After zeolite is saturated with cations, it is regenerated by being washed in saltwater and can be reused many times until it becomes 100\% unusable. This can happen after 10-11 regenerations (Guisnet, 2011). Zeolites are as effective as other ion exchange substances, but they are much cheaper than their counterparts. Due to their high cation-exchange capacity, ecological structure and low cost, zeolites are widely used in pools, reservoirs, aquariums and aquaculture farms (Yin et al., 2018).

Arctic charr (Salvelinus alpinus) is the northernmost residing freshwater fish, which is best adapted to living in cold conditions among all Salmonid fish (Johnson, 1980). As reported by Klemetsen et al. (2003), Arctic charr exhibit a high degree of biological plasticity and easily adapt to a shifting environment. The optimal temperature for the growth of Arctic charr is reported to be in the range of 10 to $15^{\circ} \mathrm{C}$ (Bebak et al., 2000), and Arctic charr can survive in water temperatures as low as $0.3^{\circ} \mathrm{C}$ (Siikavuopio et al., 2009). As determined by Thyrel M et al. (1999), Arctic charr stop feeding and growing at the critical temperature of $21.5^{\circ} \mathrm{C}$. However, Larson (2005) and Siikavuopio et al. (2014) reported a slightly lower temperature of $10-12^{\circ} \mathrm{C}$ as the most comfortable temperature range for Arctic charr. Like other salmonids, Arctic charr are grown in recirculating aquaculture systems (RAS). Arctic charr are attractive to fish farmers because of their tolerance for high density, i.e., as high as 90 to $130 \mathrm{~kg} / \mathrm{m}^{3}$ (Jansson, 2008). This fish is also attractive to consumers because of its delicious boneless fish meat, which has omega-3 fatty acids useful for human heart disease prevention (Aarset, 1999, FAO, 2014).

Sparctic charr is a hybrid created by artificially interbreeding Arctic charr (Salvelinus alpinus) and Brook trout (Salvelinus fontinalis) (Jansson, 2008). As claimed by Dumas et al. (1996), the survivability of these hybrids in the early

Copyright (C) 2019 The Authors. Published by Vytautas Magnus University. This is an open-access article distributed under the terms of the Creative Commons Attribution License (CC BY 4.0), which permits unrestricted use, distribution, and reproduction in any medium, provided the original author and source are credited. 
stages is satisfactory for aquaculture purposes, even though this indicator is lower than for the parent species. This hybrid is attractive in its exterior; meat structure and taste, which resemble those of Salmonid fish; higher water temperature tolerance; and increased resistance to several fish disease (Brännäs et al., 2011; Jansson, 2008). Based on (Muus \& Dahlstrom, 1981), Sparctic charr grow faster than its parent species and is healthier and more energetic, making it popular for recreational fishing. Some of these hybrids are fertile (Muus \& Dahlstrom), 1981. As stated in a study by (Gross et al., 2004), the first hybrid, which was created in 1890 in Germany, is still appreciated by consumers and farmers. Salvelinus spp. typically have a higher tolerance for low oxygen concentrations and higher pH limits (4 to 9.8) (McClane 1974). The optimal SPP temperature is $7.5-12.5^{\circ} \mathrm{C}$ (Piper et al., 1982, Stevenson 1987). In Canada, Brook trout show better growth and lower size variance than other salmonids (Dumas et al., 1995).

The aim of the study is to estimates the possibilities of zeolite use in Arctic charr and Hybrid charr fry for water quality control in rearing tanks.

\section{METHODS AND MATERIALS}

The Vytautas Magnus University (VMU) Aquaculture Centre ordered 20500 Arctic charr (Salvelinus alpinus) eggs and 24200 Hybrid charr (Salvelinus spp.) (Salvelinus fontinalis $\times$ Salvelinus alpinus) eggs from Canadian and Polish aquaculture farms, respectively. These eggs were then incubated in the VMU Aquaculture Center incubation room. After using $70-90 \%$ of their yolk, the hatched alevins, with an average weight of $0.1-0.15 \mathrm{~g}$, were moved to an alevin rearing system (Fig. 1) and were fed 50-60 g a day. The rearing tank dimensions were $2.47 \times 0.50 \times 0.40 \mathrm{~m}$. The fry rearing system consisted of the rearing tanks, sediment tank, trickling biofilter, ultraviolet lamp, and pump. At the beginning of the study, the tank water depth was $15 \mathrm{~cm}$. After $90 \%$ of the fry had begun to feeding, the water depth was increased to $25 \mathrm{~cm}$. The study began with 18324 Arctic charr fry (mortality of 11\%) and 20354 hybrid charr fry (mortality of 16\%). Fish biomass in the reservoirs was distributed as follows: Arctic charr accounted for $7.32 \mathrm{~kg}$ at a density of $23.74 \mathrm{~kg} \cdot \mathrm{m}^{-3}$, and hybrid charr accounted for $7.78 \mathrm{~kg}$ at a density of $26.91 \mathrm{~kg} \cdot \mathrm{m}^{-3}$.

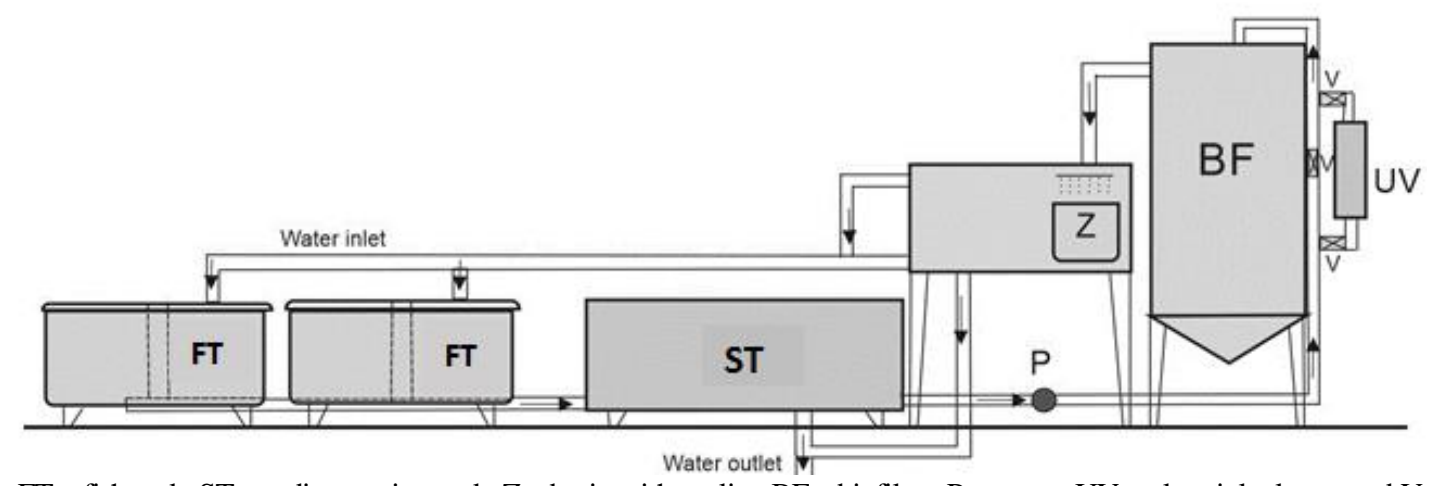

Figure 1. FT - fish tank, ST - sedimentation tank, Z - basin with zeolite, BF - biofilter, $\mathrm{P}$ - pump, UV - ultraviolet lamp, and V - valves

At the start of the study, $110 \mathrm{~g} \cdot \mathrm{d}^{-1}(1.5 \%$ of AC biomass and $1.4 \%$ of HC biomass) of feed was provided to the fish, and after 16 days, the rate was increased to $220 \mathrm{~g} \cdot \mathrm{d}^{-1}$ of feed in each tank. The feeding rate was lower than suggested by the supplier because unused feed amount and water quality parameters were taken into account. The feeding rate was reduced or completely stopped after water quality parameters worsened. All fry were grown under equal conditions in the same system, fed with identical feed and feed amount. Biomar LARVIVA proStart (Denmark) was used as feed. LARVIVA ProStart contains Bactocell ${ }^{\circledR}$.

Dead fish were removed from tanks every day. The mortality rate was established at the end of the study. Unused feed and excrement accumulated on the bottom of the tanks was pumped out manually twice a day.

After increasing the feed rate and documenting water quality studies, a vast increase of ammonium and nitrite concentration was noticed in the rearing tanks. Natural zeolite was used to reduce the amounts of these hazardous substances in the rearing tanks with as little of an investment as possible. A tank containing $20 \mathrm{~kg}$ zeolite with particle sizes of 4-8 mm was installed immediately below the biofilter; that is, before flowing into the tanks, the water from the biofilter first flowed through the zeolite using a trickling filter principle (Fig. 1). Every 10-14 hours, the zeolite was washed in $\mathrm{NaCl}$ solution and returned to the system. After the feed rate was increased, the amount of zeolite was also increased to $30 \mathrm{~kg}$.

The natural zeolite used in the study was purchased from a company in Slovakia called ZEOCEM. The chemical name for the natural zeolite is hydrated aluminosilicate of alkali metals and alkaline earth metals, which in its mineral form is known as clinoptilolite, with a cation exchange capacity (CEC) of $1.20-1.50 \mathrm{~mol} \cdot \mathrm{kg}^{-1}$. The chemical and mineral compositions of clinoptilolite are shown in Table 1.

The temperature was quite stable throughout the entire study, i.e., $9-10.30^{\circ} \mathrm{C}$. oxygen saturation was maintained at $90-120 \%$. In addition to recording the oxygen levels and temperature, the following water quality parameters were also recorded during the study: ammonium $\left(\mathrm{NH}_{4}\right)$, nitrite $\left(\mathrm{NO}_{2}\right)$, nitrate $\left(\mathrm{NO}_{3}\right)$, pH, and alkalinity (e.g., CaCO$)$. Water quality was examined using a HI 83200 multiparameter spectrophotometer (USA). Spectrphotometric chemical analysis is based on the possibility to develop an absorbing compound from a specific chemical reaction between sample and reagents. 
Table 1. Chemical and mineral compositions of clinoptilolite:

\begin{tabular}{|c|c|c|c|}
\hline Component & Percentage by weight $(\%)$ & Component & Percentage by weight $(\%)$ \\
\hline \multicolumn{2}{|c|}{ Chemical composition } & $\mathrm{TiO}_{2}$ & $0.10-0.30$ \\
\hline $\mathrm{SiO}_{2}$ & $65.00-71.30$ & $\mathrm{Si} / \mathrm{Al}$ & $4.80-5.40$ \\
\hline $\mathrm{Al}_{2} \mathrm{O}_{3}$ & $11.50-13.10$ & \multicolumn{2}{|c|}{ Mineral composition } \\
\hline $\mathrm{CaO}$ & $2.70-5.20$ & Clinoptilolite & 84 \\
\hline $\mathrm{K}_{2} \mathrm{O}$ & $2.20-3.40$ & Cristobalite & 8 \\
\hline $\mathrm{Fe}_{2} \mathrm{O}_{3}$ & $0.70-1.90$ & Clay mica & 4 \\
\hline $\mathrm{MgO}$ & $0.60-1.20$ & Plagioclase & $3-4$ \\
\hline $\mathrm{Na}_{2} \mathrm{O}$ & $0.20-1.30$ & Rutile & $0.10-0.30$ \\
\hline
\end{tabular}

The homogeneity of the analysed parameters was checked using Leven's test. One-way analysis of variance (ANOVA) was used to determine any significant differences in Total statistical analysis was evaluated as significant if $P<0.05$. Statistical analysis was done using the STATISTICA 10 software.

\section{RESULTS}

The $\mathrm{pH}$ and water temperature during the study period ranged from 7.90 to 8.15 and from $8.30^{\circ} \mathrm{C}$ to $10.30^{\circ} \mathrm{C}$, respectively. The dissolved oxygen concentration fluctuated from $7.88 \mathrm{mg} \cdot \mathrm{L}^{-1}$ to $10.2 \mathrm{mg} \cdot \mathrm{L}^{-1}$. The alkalinity ranged from 210 to $280 \mathrm{mg}\left(\mathrm{CaCO}_{3} \cdot \mathrm{L}^{-1}\right)$, and the nitrate concentration was zero during the study period. The water quality parameters are shown in Table 2.

Table 2. Average values of water parameters in rearing water during the study period

\begin{tabular}{|c|c|c|c|}
\hline \multirow{2}{*}{ Parameter } & \multicolumn{3}{|c|}{ Treatments } \\
\hline & $20 \mathrm{~kg}$ zeolite (feed: $110 \mathrm{~g} / \mathrm{d}$ ) & $30 \mathrm{~kg}$ zeolite (feed: $110 \mathrm{~g} / \mathrm{d}$ ) & $30 \mathrm{~kg}$ zeolite (feed: $220 \mathrm{~g} / \mathrm{d}$ ) \\
\hline Temperature, ${ }^{\circ} \mathrm{C}$ & $9.58 \pm 0.39^{\mathrm{a}}$ & $9.9 \pm 0.22^{\mathrm{a}}$ & $9.17 \pm 0.53^{\mathrm{a}}$ \\
\hline Oxygen, mg/l & $10.09 \pm 0.45^{\mathrm{b}}$ & $9.71 \pm 0.26^{\mathrm{a}}$ & $9.37 \pm 0.59^{\mathrm{a}}$ \\
\hline Ammonium-N $\left(\mathrm{NH}_{4}\right), \mathrm{mg} / \mathrm{l}$ & $0.308 \pm 0.105^{\mathrm{a}}$ & $0.254 \pm 0.119^{b}$ & $0.238 \pm 0.075^{\mathrm{b}}$ \\
\hline Nitrite $\mathrm{NO}_{2}, \mathrm{mg} / \mathrm{l}$ & $0.108 \pm 0.032^{\mathrm{a}}$ & $0.094 \pm 0.038^{\mathrm{a}}$ & $0.090 \pm 0.032^{\mathrm{b}}$ \\
\hline $\mathrm{pH}$ & $8.06 \pm 0.053^{\mathrm{a}}$ & $8.01 \pm 0.074^{\mathrm{a}}$ & $8.01 \pm 0.051^{\mathrm{a}}$ \\
\hline Alkalinity (as $\mathrm{CaCO}_{3}$ ), $\mathrm{mg} / \mathrm{l}$ & $245.77 \pm 3.44^{\mathrm{a}}$ & $237.00 \pm 16.81^{\mathrm{a}}$ & $232.69 \pm 16.41^{\mathrm{b}}$ \\
\hline
\end{tabular}

Fig. 2 shows the variation in the dissolved oxygen and temperature in the rearing water during the study period. The water temperature was stable and varied no more than $\pm 0.5^{\circ} \mathrm{C}$ during the day.

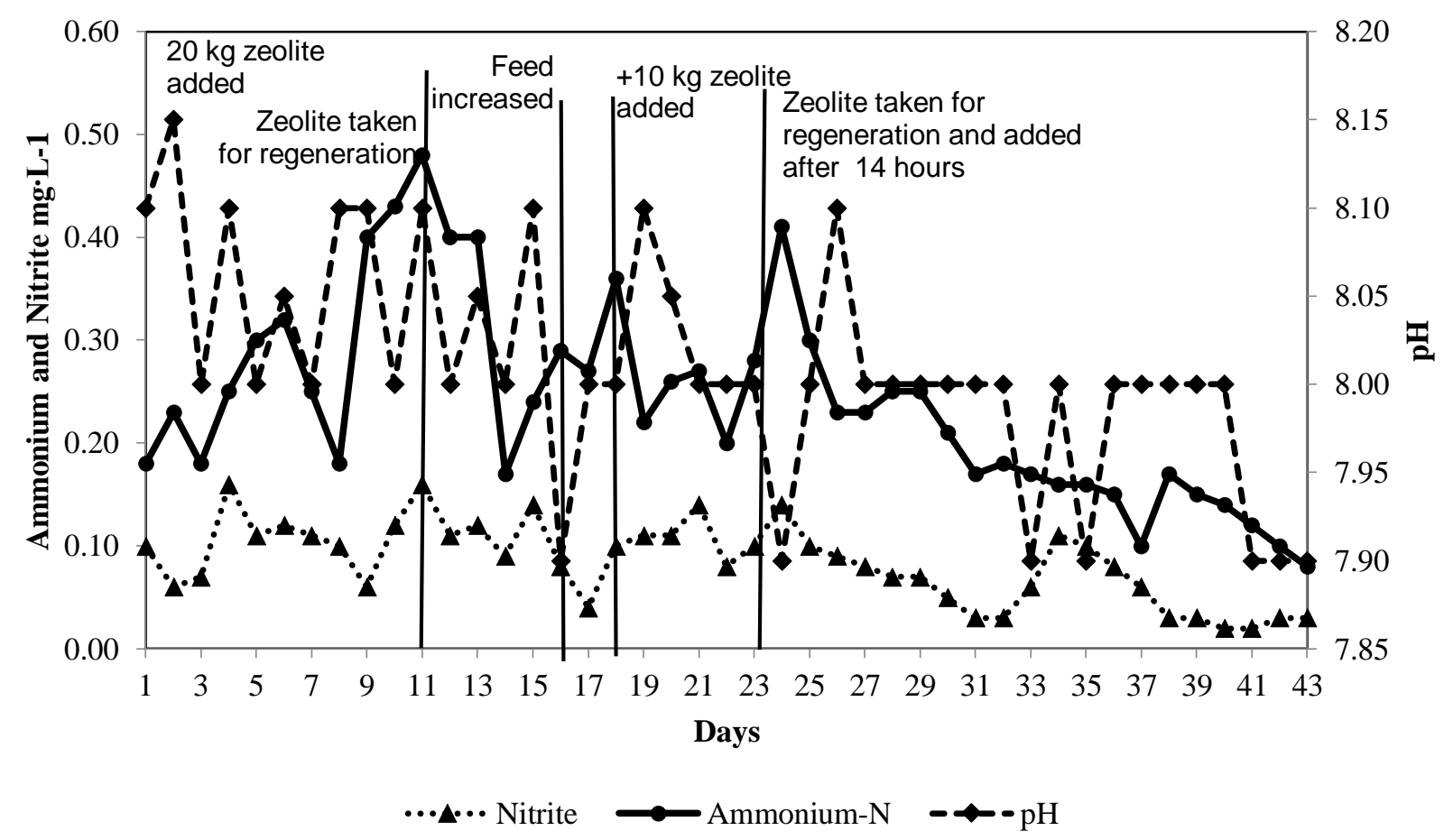

Figure 2. Variation of ammonia, nitrite and $\mathrm{pH}$ in rearing water during the study period 
Increased amounts of ammonia and nitrite were observed in the rearing water, ranging from $0.4-0.48 \mathrm{mg} \cdot \mathrm{L}^{-1} \mathrm{and}$ $0.06-0.12 \mathrm{mg} \cdot \mathrm{L}^{-1}$, respectively. The natural zeolite was used to reduce the ammonia and nitrite concentration in the rearing water. The addition of $20 \mathrm{~kg}$ of zeolite reduced the concentrations of ammonium and nitrite in the system to 0.07 and 0.09 $\mathrm{mg} \cdot \mathrm{L}^{-1}$, respectively. The alkalinity decreased to $210 \mathrm{mg} \mathrm{CaCO} \cdot \mathrm{L}^{-1}$, and the $\mathrm{pH}$ was 8.0. The feeding rate was $110 \mathrm{~g} \cdot \mathrm{d}^{-1}$ for each tank.

After 16 days, the feeding rate increased to $220 \mathrm{~g} \cdot \mathrm{d}^{-1}$ to each tank. When the feeding rate was increased, the concentration of ammonia and nitrite increased, with the ammonia concentration reaching $0.29 \mathrm{mg} \cdot \mathrm{L}^{-1}$ and the nitrite concentration reaching $0.08 \mathrm{mg} \cdot \mathrm{L}^{-1}$. At the end of the 18th day, the zeolite was taken from the system for regeneration, and the concentrations of ammonia and nitrite increased to $0.36 \mathrm{mg} \cdot \mathrm{L}^{-1}$ and $0.1 \mathrm{mg} \cdot \mathrm{L}^{-1}$, respectively. Because the feeding rate had been increased, an additional $10 \mathrm{~kg}$ zeolite was added to the system for the regulation of the ammonia and nitrite concentrations in the rearing water. The amount of ammonia over the 14 hours decreased to $0.22 \mathrm{mg} \cdot \mathrm{L}^{-1}$ and the nitrite to $0.11 \mathrm{mg} \cdot \mathrm{L}^{-1}$. The concentration of the ammonia was maintained between $0.22 \mathrm{mg} \cdot \mathrm{L}^{-1}$ and $0.28 \mathrm{mg} / \mathrm{l}^{-1}$ and the nitrite between $0.11 \mathrm{mg} \cdot \mathrm{L}^{-1}$ and $0.14 \mathrm{mg} \cdot \mathrm{L}^{-1}$ until day 23 of the study, after which the zeolite was removed from the system for regeneration in $\mathrm{NaCl}$ solution. While the zeolite was being regenerated, the concentrations of ammonia and nitrite increased to $0.41 \mathrm{mg} \cdot \mathrm{L}^{-1}$ and $0.14 \mathrm{mg} \cdot \mathrm{L}^{-1}$, respectively. Once regenerated, the zeolite was returned to the system, and the concentrations of ammonia and nitrite decreased to safe levels of $0.1 \mathrm{mg} \cdot \mathrm{L}^{-1}$ and $0.03 \mathrm{mg} \cdot \mathrm{L}^{-1}$, respectively. The alkalinity decreased to $215 \mathrm{mg} \mathrm{CaCO}{ }_{3} \cdot \mathrm{L}^{-1}$, and the $\mathrm{pH}$ was 8.0.

\section{DISCUSSION}

Great water quality has to be maintained to grow Arctic charr at high density because, at this stage, bacterial gill infections are quite common; hence, the rearing water needs to have a high amount of oxygen and low amounts of suspended solids, carbon dioxide and ammonia. During the study, the water quality in the system was controlled carefully to replicate the recommended values for Arctic charr growth.

Salmonid fish are usually sensitive to water $\mathrm{pH}$ changes, but Arctic charr are less sensitive than other salmonid fish. Salmonids can tolerate a $\mathrm{pH}$ between 5 and 9, but maximum productivity is achieved when the pH is between 6.5 and 8.5 (Jobling, 1994). In this study, the $\mathrm{pH}$ level never decreased below 7.9 and never increased above 8.1.

Fish use oxygen to convert feed into energy and biomass. Depending on the fish species, as stated by (Pillay and Kutty, 2005), the necessary minimal concentration of dissolved oxygen in water needs to be approximately $5.0 \mathrm{mg} \cdot \mathrm{L}^{-1}$ for warmwater fish and $7.0 \mathrm{mg} \cdot \mathrm{L}^{-1}$ for coldwater fish to obtain optimal fish growth: salmonid fish are the exception to this guideline, as their optimal oxygen saturation needs to be at least 70-80\%; i.e. the dissolved oxygen cannot be lower than $6.0 \mathrm{mg} \cdot \mathrm{L}^{-1}$ or higher than $9.0 \mathrm{mg} \cdot \mathrm{L}^{-1}$. Once the oxygen saturation falls below $70 \%$, the growth rate and feed consumption are reduced (Jobling, 1994). When the saturation level is higher than 120-140\%, fish welfare problems arise from oxidative stress, and the fish will show increased sensitivity to diseases and higher mortality (Aquafarmer 2004). In this study, oxygen saturation in the water is $84-110 \%$, which corresponds to the recommended values by (Sæther et al., 2015). However, Beuvard et al. (2014) proposed optimizing Arctic charr growth by maintaining an oxygen saturation of 60$80 \%$. After commencing experiments with various levels of oxygen saturation $(60 \%, 80 \%, 100 \%, 120 \%$ and $140 \%)$, the authors determined that $60 \%-140 \%$ saturation showed no discernible difference between growth rates, but in the cited study, fish age was not considered. However, feed conversion and oxygen consumption increased significantly as the oxygen saturation levels progressively increased. Both routine and active metabolic rates (measured as $\mathrm{O}_{2}$ consumption) increased significantly with increased oxygen saturation. Salvelinus spp. has a higher tolerance toward low oxygen concentration and pH levels (4 to 9.8) (McClane 1974). According to(Sæther et al., 2015), Arctic charr oxygen consumption varies depending on body weight, feed and growth rates, activity level, swimming speed, water temperature and stress level. Properly fed fish that have good growth rates consume, on average, more than $150 \mathrm{mg} \mathrm{O}_{2} \mathrm{~kg}^{-1} \cdot \mathrm{h}^{-1}$, and right after feeding, oxygen consumption increases to 40-50\% above the average.

Based on Jobling, 1994, the temperature for Arctic charr fry growth should be $8-10^{\circ} \mathrm{C}$ if the fry are being fed with artificial feed. The optimal growth temperature for Arctic charr fry and fingerlings is from $13-18^{\circ} \mathrm{C}$, whereas they grow better, consume feed and are more resilient to diseases when the water temperature is $11-12^{\circ} \mathrm{C}$ (Siikavuopio et al., 2013; Larsson 2005). However, Larson (2005) and Siikavuopio et al. (2014) reported a slightly lower temperature of $10-12^{\circ} \mathrm{C}$ as the most comfortable temperature range for Arctic charr. The optimal temperature for Salvelinus spp. has been reported as 7.5-12.5 ${ }^{\circ}$ C. (Piper et al., 1982, Stevenson 1987). During this study, the water temperature in the rearing tanks was between $8.3^{\circ} \mathrm{C}$ and $10.3^{\circ} \mathrm{C}$, but it did not vary by more than $0.5^{\circ} \mathrm{C}$ on any given day. Water temperature boundaries were optimal for both species of fry.

Nitrogenous compounds and metabolites, such as ammonia $\left(\mathrm{NH}_{3}\right)$, nitrites $\left(\mathrm{NO}_{2}\right)$ and nitrates $\left(\mathrm{NO}_{3}\right)$, frequently accumulate in intense UAS and semiclosed rearing systems even if the water is frequently changed (Colt et al., 2009, Lekang 2007). When fish are kept in RAS, the water is usually cleaned in biofilters to remove ammonia (Colt et al. 2009, Lekang 2007). However, biofilter effectiveness is decreased at low temperatures. As stated by (Van der Werf , 2012), temperature change can influence the bacterial activity of the biofilter. Van der Werf proved that, at temperatures lower than $10^{\circ} \mathrm{C}$ and higher than $32^{\circ} \mathrm{C}$, nitrification processes are limited in aquaculture systems. High ammonia and nitrite concentrations are toxic to fish; if this toxicity is not removed for a longer period of time, it causes great stress to the fish, and the consequences can be lethal. Increased $\mathrm{NH}_{4}$ and $\mathrm{NO}_{2}$ levels were encountered during the study. The recommended ammonia quantity for salmonid fish is $0.015 \mathrm{mg} \cdot \mathrm{L}^{-1}$ (MacIntyre et al., 2008; Skybakmoen et al., 2009); however, different nitrite concentration boundary values for Arctic charr have been noted, including $<0.1 \mathrm{mg} \cdot \mathrm{L}^{-1}$, as reported by (Jensen, 
2003, Lekang, 2007; MacIntyre et al., 2008), and $<0.015 \mathrm{mg} \cdot \mathrm{L}^{-1}$ or $0.012 \mathrm{mg} \cdot \mathrm{L}^{-1}$ for the first feedings of Arctic charr (Johnston, 2008). An increased amount of ammonia and nitrite inside fry rearing tanks was noticed at the start of the study. One explanation may be that biofilters work better in higher temperature water, as stated before. During the study, the water temperatures in the systems used with the Arctic and Hybrid char were between $8.3^{\circ} \mathrm{C}$ and $10.3^{\circ} \mathrm{C}$; therefore, the biofilter worked at lower efficiency than projected. Since the feed amount was reduced and constant TSS removal did not help, zeolite was used to reduce the concentrations of these parameters. Many studies have been published on zeolite use to effectively remove ammonium $\mathrm{NH}_{4}{ }^{+}$from waste (Almutairi and Weatherley, 2015; Casadellà et al., 2016; Zhang et al., 2017, Zhou and Boyd, 2014). Zeolite's effectiveness in lowering the ammonia concentration in rearing water is proven, and as stated by Emadi et al. (2001) and Aly et al. (2016), the effectiveness was able to reach $83 \%$ when the ammonia started at $\leq 1.0 \mathrm{mg} \cdot \mathrm{L}^{-1}$. Öz et al. (2016) proved that zeolite inserted in a net bag reduced ammonia concentration in a rearing tank by $72 \%$, whereas zeolite placed directly into water in the tank reduced the ammonia level by only $33 \%$. Ghiasi and Jasour (2012) studied water quality parameter changes for aquarium-grown Pterophyllum scalare by using different values of Iranian natural zeolite (clinoptilolite) and determined that the best results were achieved in reducing ammonia concentration in rearing water with $10 \mathrm{~g} \cdot \mathrm{l}^{-1}$ ammonia. (Obradović et al. 2006) used Ambizel-V natural zeolite, which has a particle size of $0.8-2.5 \mathrm{~cm}$, to improve rainbow trout growth conditions. Once applied, $60 \mathrm{~kg}$ of zeolite considerably reduced the general water hardness and the nitrate and ammonia concentrations. As stated by (Ghasemi et al., 2016), zeolite particle size also influences the effectiveness of ammonia formation removal. Ammonia absorption productivity in freshwater RAS was better when smaller 0.7-1.0 mm zeolite particles were used than when 1.0-1.4 mm zeolite particles were used for the same holding time period (Mwale 2001). Similar results were reported by (Nguyen and Tanner 1998), who studied different sized particles of clinoptilolite and mordenite and proved that zeolite with particle sizes of $0.25-0.50 \mathrm{~mm}$ was more effective in removing ammonia from waste than zeolite with a particle size of 2-2.83 $\mathrm{mm}$. These authors state that zeolite particle size both influences ammonia removal effectiveness, the holding time period and the chemical structure of the zeolite. The higher level of ammonia removal effectiveness by fine zeolite can be explained by the larger surface size and, therefore, the shorter diffusion path length (Chiayvareesajja\&Boyd, 1993, Alshameria et al., 2017) because finer particles are more likely to reach exchange sites by cations. If zeolite is used in a column or as a medium for constant filtration, the use of finer particles can contribute to lower pressure and more frequent media jams, which results in a reduced filtration rate, making the use of fine zeolite in aquaculture impractical (Semmens, 1983). Considering these observations, 4-8 $\mathrm{mm}$ size zeolite was used in this study.

Zeolite started working 6-8 hours after its inclusion into the system. This result is similar to that of (Nicolae et al., 2017), who determined that after water had passed through the zeolite column (166 g zeolite) for 8 hours, the $\mathrm{NH}_{4}$ concentration was lowered from $0.176 \mathrm{mg} \cdot \mathrm{L}^{-1}$ to $0.10 \mathrm{mg} \cdot \mathrm{L}^{-1}$, and the nitrite concentration was lowered from $0.569 \mathrm{mg}$. $\mathrm{L}^{-1}$ to $0.398 \mathrm{mg} \cdot \mathrm{L}^{-1}$ in the aquarium water in which common carp fish were grown.

In intensive RAS, the nitrite level may become elevated when the ammonia oxidation level to nitrites exceeds the nitrite oxidation to nitrates level (Bjorn-Steinar et al., 2015). As stated by Sæther et al., 2015, safe levels of ammonia, nitrites and nitrates for Arctic charr are not fully known. Intermediate ammonia oxidation products—nitrites $\left(\mathrm{NO}_{2}\right)$ - are harmful for water organisms in relatively low concentrations. (Pillay and Kutty 2005) state that nitrite levels in aquaculture systems need to be lower than $1.0 \mathrm{mg} \mathrm{NO} 2-\mathrm{N} \cdot \mathrm{L}^{-1}$. The lethal concentration for rainbow trout (Oncorhynchus mykiss) after 24 hours of captivity was reported as $1.8 \mathrm{mg} \mathrm{NO}-\mathrm{N} \cdot \mathrm{L}^{-1}$ (Hagopian and Riley, 1998). However, (MacIntyre et al., 2008: Skybakmoen et al,. 2009) state that, based on Arctic charr growth inside recirculating systems and Atlantic salmon and other salmonid fish growth in freshwater practice, the nitrite concentration must be less than $0.1 \mathrm{mg} \cdot \mathrm{L}^{-1}$ and must not exceed $0.2 \mathrm{mg} / \mathrm{l}$. Furthermore, according to (Jensen, 2003, Lekang, 2007; MacIntyre et al., 2008 Jobling, 2010), if biofilter effectiveness is reduced in low temperatures, the addition of chloride in the form of salt (sodium chloride) or calcium chloride at a rate of 10 $\mathrm{mg} \cdot \mathrm{L}^{-1}$ chloride for each $1 \mathrm{mg} / \mathrm{L}$ of nitrite will reduce the toxic effects of the nitrite on the fish (Syrakov et al., 2015). In the studied system, salt was used to reduce the toxicity of the nitrites, and the rearing water salinity was 2 ppt.

The results show that zeolite is effective in lowering ammonia and nitrite concentrations in fish rearing water. Furthermore, zeolite helps regulate water $\mathrm{pH}$ levels. Notably, one of zeolite's weaknesses is that it needs to frequently regenerate in intensive enclosed aquaculture systems. Emadi et al., 2001 also determined that zeolite lowers the amount of ammonia ions in the RAS water when salinity is lower than $10 \mathrm{mg} / \mathrm{l}$, but the main weakness was that after several hours of zeolite use, the zeolite ion exchange effectiveness was lowered; therefore, frequent zeolite regeneration is necessary.

After zeolite is saturated with cations, it is regenerated by being washed in saltwater and can be reused many times until it becomes $100 \%$ unusable. This can happen after 10-11 regenerations (Guisnet, 2011). Zeolites are as effective as other ion exchange substances, but they are much cheaper than their counterparts. Due to their high cation-exchange capacity, ecological structure and low cost, zeolites are widely used in pools, reservoirs, aquariums and aquaculture farms (Yin et al., 2018).

\section{CONCLUSIONS}

1. Zeolite decreased the concentration of ammonia and nitrites by $22.7 \%$ and $16.7 \%$, respectively, during the study period.

2. The obtained results suggest that zeolite is suitable for water quality management in cold water recirculating aquaculture system with as little of an investment as possible.

\section{REFERENCES}


1. Aarset B. 1999. Aquaculture development, institution building and research and development policy: Norwegiansalmon and Arctic char farming as cases. Aquaculture Economics and Management, Vol. 3, pp. $177-191$. https://doi.org/10.1080/13657309909380244

2. Almutairi A., Weatherley,L.R. 2015. Intensification of ammonia removal from waste water in biologically active zeolitic ion exchange columns. Journal of Environmental Management, Vol. 160, pp. 128-138. doi:10.1016/j.jenvman.2015.05.033.

3. Alshameria A., He H., Zhu J., Xi Y., Zhu R., Ma L., Tao Q. 2017. Adsorption of ammonium by different natural clay minerals: characteriazation, kinetics and adsorption isotherms. Applied Clay Science, Vol. 159, pp. 83-93. https://doi.org/10.1016/j.clay.2017.11.007

4. Aly H.A., Abdel-Rahim M.M., Lotfy A.M., Abdelaty B.S., Sallam G.R. 2016. The Applicability of Activated Carbon, Natural Zeolites, and Probiotics (EM®) and Its Effects on Ammonia Removal Effciency and Fry Performance of European Seabass Dicentrarchus labrax. Journal of Aquaculture Research \& Development, Vol. 7, Iss. 11, pp. 2-8. https://doi.org/10.4172/2155$\underline{9546.1000459}$

5. Bebak J., Hankin, J.A., Summerfelt S.T. 2000. Effect of water temperature on survival of eyed eggs and alevins of Arctic char. North American Journal of Aquaculture, Vol. 62, pp. 139-143. https://doi.org/10.1577/15488454(2000)062<0139:EOWTOS>2.0.CO;2

6. Beuvard Ch., Imsland A. K., Thorarensen H. 2014. The effect of oxygen saturation on growth and metabolic rate of Arctic charr, salvelinus alpinus. Conference: Aquaculture Europe 2014, Donostia-San Sebastián, Spain.

7. Brännäs E., Larsson S., Sæther B. S., Siikavuopio S. I., Thorarensen H., Sigurgeirsson Ó., Jeuthe H. 2011. Arctic charr farming. Production of juveniles; a manual. Swedish University of Agricultural Sciences. https://pub.epsilon.slu.se/8468/1/Brannas_E_etal_111125.pdf Date of access 03/04/2019.

8. Casadellà A., Kuntke P., Schaetzle O., Loos K. 2016. Clinoptilolite-based mixed matrix membranes for the selective recovery of potassium and ammonium. Water Recourse, Vol. 90, pp. 62-70. https://doi.org/10.1016/j.watres.2015.12.017

9. Chiayvareesajja S., Boyd C.E. 1993. Effects of zeolite, formalin, bacterial augmentation, and aeration on total ammonia nitrogen concentrations. Aquaculture, Vol. 116, pp. 33-45. https://doi.org/10.1016/0044-8486(93)90220-S

10. Colt J., Watten B., Rust M. 2009. Modeling carbon dioxide, pH, and un-ionized ammonia relationships in serial reuse systems. Aquacultural Engineering, Vol. 40, pp. 28-44. https://doi.org/10.1016/j.aquaeng.2008.10.004

11. Dumas S., J.M. Blanc F. Vallee C. Audet J., De La Noeue J. 1996. Survival, growth, sexual maturation and reproduction of brook char, Salvelinus fontinalis (Mitchill), Arctic char, Salvelinus alpinus L. and their hybrids. Aquaculture Recourse, Vol. 27, pp. 245-253. https://doi.org/10.1111/j.1365-2109.1996.tb00991.x

12. Emadi H., Nezhad J.E., Pourbagher H. 2001. In vitro Comparison of Zeolite (Clinoptilolite) and Activated Carbon as Ammonia Absorbants in Fish Culture. Naga The ICLARM Quarterly, Vol. 24, Iss. 1-2, pp. 1-3. http://pubs.iclarm.net/Naga/Naga24$1 \& 2 /$ pdf/aquabyte $\% 204 . p d f$

13. FAO. 2014. The State of World Fisheries and Aquaculture 2012. FAO Fisheries and Aquaculture, Food and Agriculture organization of the United Nations, Rome, Italy. http://www.fao.org/3/i9540en/i9540en.pdf

14. Ghasemi Z., Sourinejad I., Kazemian H., Rohani,S. 2016. Application of zeolites in aquaculture industry: a review. Reviews in Aquaculture, Vol. 10, pp. 1-21. https://doi.org/10.1111/raq.12148

15. Ghiasi F., Jasour M. S. 2012. The effects of natural Zeolite (Clinoptilolite) in Water Quality, growth performance and Nutritional Parameters of fresh water aquarium fish, Angel (Pterophyllum scalare). International Journal of Research in Fisheries and Aquaculture, Vol. 2, Iss. 3, pp. 22-25.

16. Gross R., Gum B., Reiter R., Kuhn R. 2004. Genetic introgression between Arctic char (Salvelinus alpinus) and brook trout (Salvelinus fontinalis) in Bavarian hatchery stocks inferred from nuclear and mitochondrial DNA markers. Aquaculture International, Vol. 12, pp. 19-32. DOI:10.1023/B:AQUI.0000017184.92614.e1

17. Guisnet M. 2011. Poisoning of zeolite catalysts. Deactivation and Regeneration of Zeolite Catalysts: pp. 101-114. https://doi.org/10.1142/97818481663870006

18. Hagopian D.S., Riley J.G. 1998. A Closer Look at the Bacteriology of Nitrification. Aquacultural Engineering, Vol. 18, Iss. 4, pp. 223-244. https://doi.org/10.1016/S0144-8609(98)00032-6

19. Jansson K. 2008. NOBANIS - Invasive Alien Species Fact Sheet - Salvelinus fontinalis. From: Online Database of the North European and Baltic Network on Invasive Alien Species - NOBANIS www.nobanis.org. Date of access 03/04/2019.

20. Jensen, F. B. 2003. Nitrite disrupts multiple physiological functions in aquatic animals. Comparative Physiology and Biochemistry, Vol. 135A, pp. 9-24. https://doi.org/10.1016/S1095-6433(02)00323-9

21. Jobling M., 1994. Fish Bioenergetics. Chapman \& Hall, London.

22. Jobling M., 2010. Fish culture: the rearing environment. In Le François, N. R., M. Jobling, C. Carter \& P. Blier (eds), Finfish Aquaculture Diversification. CABI, Wallingford, pp. 33-60. https://doi.org/10.1079/9781845934941.0033

23. Johnson L. 1980. The Arctic charr, Salvelinus alpinus. In Balon, E. K. (Editor), Charrs, Salmonid Fishes of the Genus Salvelinus. W. Junk, The Haguem. pp. 15-98.

24. Klemetsen A., Amundsen P-A., Dempson J. B., Jonsson B., Jonsson N., O‘Connell M. F., Mortensen E. 2003. Atlantic salmon Salmo salar L., brown trout Salmo trutta L. and Arctic charr salvelinus alpinus (L.): a review of aspects of their life histories. Ecology of Freshwater Fish, Vol. 12, pp. 1-59. https://doi.org/10.1034/j.1600-0633.2003.00010.x

25. Larsson S. 2005. Thermal preference of Arctic charr, Salvelinus alpinus, and brown trout, Salmo trutta-implications for their niche segregation. Environmental Biology of Fishes, Vol. $73, \quad$ pp. 89-96. https://link.springer.com/content/pdf/10.1007\%2Fs10641-004-5353-4.pdf 
26. Lekang O. I. 2007. Aquaculture Engineering. Blackwell Publishing, Oxford. https://doi.org/10.1002/9780470995945

27. MacIntyre C. M., Ellis T., North B. P., Turnbull J. F., 2008. The influences of water quality on the welfare of farmed rainbow trout. In Branson, E. J. (Editor), Fish welfare. Blackwell Publishing, Oxford, pp. 150-184. https://doi.org/10.1002/9780470697610.ch10

28. McClane A.J. 1974. McClane's New Standard Fishing Encyclopedia. Holt, Rinehart and Winston Inc., New York.

29. Mwale M., Kaiser H. 2001. 31-P-12-Ammonia removal from water by ion exchange using South African and Zambian zeolite samples and its application in aquaculture. Studies in Surface Science and catalysis, Vol. 135, p. 371. https://doi.org/10.1016/S0167-2991(01)81875-9

30. Nguyen M.L., Tanner C.C. 1998. Ammonium Removal from Wastewaters Using Natural New Zealand Zeolites. New Zealand. Journal of Agricultural Reseach, Vol. 41, Iss. 3, pp. 427-446. https://doi.org/10.1080/00288233.1998.9513328

31. Nicolae C. G., Sava S. C., Marin M. P., Pogurschi E., Sava B. A. 2017. Innovative solutions for removing nitrogen compounds from water of recirculating aquaculture systems using clinoptilolite natural zeolites. Current Trends in Natural Sciences, Vol. 6, Iss. 11, pp. 105-109.

32. Obradović S., Adamović M., Vukašinović M., Jovanović R., Levic J. 2006. The application Effects of natural Zeolite in Feed and Water on Production Results of Oncorhynchus mykiss (Walbaum). Romaniann Biotechnological Letters, Vol. 11, pp. $3005-3013$. https://pdfs.semanticscholar.org/0cb9/2ca71192c8f6f95c59c64d1e31a5757bf4cf.pdf

33. Öz M., Şahin D., Aral O. 2016. The Effect of Natural Zeolite Clinoptilolite on Aquarium Water Conditions. Hacettepe Journal of Biology and Chemistry, Vol. 44, Iss. 2, pp. 205-208. https://doi.org/10.15671/HJBC.20164418130

34. Pillay T.V.R., Kutty M.N. 2005. Aquaculture, Principles and Practices, 2nd Edition. Blackwell Publishing Ltd, Oxford, UK. 630 p.

35. Piper R.G., McElwain I.B., Orme L.E., McCraren J.P., Fowler L.G., Leonard J.R. 1982. Fish Hatchery Management. US Department of the Interior, Fish and Wildlife Service, Washington, DC.

36. Semmens M. J. 1983. Cation exchange properties of natural zeolites. In: Pond WG, Mumpton FA (eds) Proceedings of the ZeoAgriculture: Use of Natural Zeolites in Agriculture and Aquaculture, pp. 45-53. Westview Press, Colorado.

37. Sæther B.S., Siikavuopio S. I., Jobling M. 2015. Environmental conditions required for intensive farming of Arctic charr (Salvelinus alpinus (L.)). Hydrobiologia, Vol. 783, pp. 347-359. https://doi.org/10.1007/s10750-015-2572-y

38. Siikavuopio S.I., Skybakmoen S., Sæther B.S. 2009. Comparative growth study of wild- and hatchery produced Arctic charr (Salvelinus alpinus L.) in a coldwater recirculation system. Aquacultural Engineering, Vol. 41, pp. $122-126$. https://doi.org/10.1016/j.aquaeng.2009.06.006

39. Siikavuopio S. I., Foss A., Sæther B.S., Gunnarsson,S., Imsland,A. K. 2013. Comparison of the growth performance of offspring from cultured versus wild populations of Arctic charr, Salvelinus alpinus (L.), kept at three different temperatures. Aquaculture Research, Vol. 44, pp. 995-1001. https://doi.org/10.1111/j.1365-2109.2012.03112.X

40. Siikavuopio, S. I., Sæther, B.S., Johnsen, H., Evensen, T., Knudsen, R., 2014. Temperature preference of juvenile Arctic charr originating from different thermal environments. Aquatic Ecology, Vol. 48, 313-320. https://doi.org/10.1007/s10452-014-9485$\underline{0}$

41. Stevenson J. P. 1987. Trout farming manual, 2nd edition. Fishing news Books, Farnham, xii +259

42. Skybakmoen S., Siikavuopio S. I., Sæther B.S. 2009. Coldwater RAS in an Arctic charr farm in Northen Norway. Aquaculture Engineering, Vol. 41, pp. 114-121. https://doi.org/10.1016/j.aquaeng.2009.06.007

43. Thyrel, M., Berglund, I., Larrson, S., Näslund, I. 1999.Upper thermal limits for feeding and growth of O+ Arctic charr. Article No. jfbi.1999.096, available at http://www.idealibrary.com.on

44. Van der Werf, P. 2012. Biofiltration and Water Temperature. http://earthanedge.com/biofiltration-and-water-temperature/

45. Yin H., Yang Ch., Jis Y., Chen H., Gu X. 2018. Dual removal of phosphate and ammonium from high concentrations of aquaculture wastewaters using an efficient two-stage infiltration system. Science of the total Environmetal, Vol. 635, pp. 936946. https://doi.org/10.1016/j.scitotenv.2018.04.218

46. Zhang E., Zhou Z., An Y., Du S., Ruan D., Zhao C. Ren N., Tian X. 2017. Optimatization for zeolite regeneration and nitrogen removal performance of a hypochlorite-chlorite regerant. Chmosphere, Vol. 178, pp. 565-572. https://doi.org/10.1016/j.chemosphere.2017.03.091

47. Zhou L., Boyd C.E. 2014. Total ammonia nitrogen removal from aqueous solutions by the natural zeolite, mordenite: a laboratory test and experimental study. Aquaculture, Vol. 432, pp. 252-257. https://doi.org/10.1016/j.aquaculture.2014.05.019 